\title{
Research on the Innovation of Practice Teaching Model of Information Management Specialty in Higher Vocational Colleges*
}

\author{
Shaoqin $\mathrm{Lu}$ \\ School of Economics and Business Management \\ Changzhou College of Information Technology \\ Changzhou, China
}

\begin{abstract}
With the advancement of information technology, the management methods and management ideas of companies are also constantly developing. More and more companies are developing informationization, and using information software systems to conduct business management of enterprises. With the shortage of enterprise information management talents, there is an urgent need for higher vocational colleges to keep up with the company's talent needs, and to cultivate skilled professionals who meet the company's skill requirements to carry out informationization and management of the company. By analyzing the specifications and objectives of information management talents in higher vocational colleges, the teaching content and design principles of professional practice courses are obtained. The corresponding measures and methods are proposed in the innovation of practical course teaching models. The training methods of information management talents in higher vocational colleges have put forward corresponding suggestions.
\end{abstract}

Keywords-higher vocational colleges; information management; practical courses; teaching mode

\section{INTRODUCTION}

Enterprise Resource Planning (referred to as ERP) is a system platform that integrates advanced modern management ideas and management methods to provide enterprises with functional affairs management and decision support based on information technology. With the development of economic globalization, the application of information technology in enterprises has received more and more attention. More and more companies are using ERP software systems to manage the company, and enterprise information management talents (especially ERP software System application and implementation talents), as the specialized talents and backbones of enterprise management informationization, they are increasingly welcomed by society and enterprises. At the same time, with the close cooperation between enterprises and colleges, great changes have taken place in the way of

* Jiangsu University of Philosophy and Social Science Outstanding Innovation Cultivating Team Construction Project (No 2017ZSTD035) phased research results.

Changzhou College of Information Technology, Manufacturing and Internet Fusion Innovation Development Research Base (No CXPT201702R) phased research results. cultivating their knowledge and skills to students. Higher vocational colleges should use different teaching means and teaching methods in the teaching model of practical courses for information management specialty, the continuous improvement of the teaching content and form of the practical courses will promote the alignment of the talent training standards in the vocational colleges with the skills needs of the actual job positions of the company.

The innovation of the practical teaching mode of information management specialty in higher vocational colleges takes Changzhou College of Information Technology as an example, and the specialty is business management specialty (management informationization direction).

\section{INFORMATION MANAGEMENT SPECIALTY TRAINING OBJECTIVES}

The goal of talents training for business management specialty (management informationization direction) mainly targets two types of enterprises, manufacturers and ERP software suppliers. And it mainly trains complex skilled talents who understand both information technology and management technology. In addition to being able to engage in functional business-type management positions in manufacturing companies, such as production, logistics, finance, and human resource management positions, ERP software companies will also train sales, implementation, maintenance and service talents of management information software systems (ERP software systems), such as ERP pre-sales consultants, ERP sales consultants, ERP implementation consultants, ERP service consultants, and ERP advisory consultants. In manufacturing companies, the graduates of information management majors are responsible for the handling of specific functional matters, and use the ERP system to manage the various positions. They are the end users of the ERP software system. In the ERP software company, graduates in information management are responsible for the implementation, marketing, promotion, maintenance, and service of ERP software for customer companies, and are responsible for the customization of ERP software.

Based on the above two types of enterprises' job and job responsibilities, information management talents must have 
solid management technology and information technology as a basis, be familiar with the company's production and operation processes, and be able to classify and forecast customer demand information. Communicate with customers, understand customer needs and implement them in the ERP software system. At the same time, we must be familiar with the business processes of the actual positions of the company, have ERP software system sales, consulting, training, on-line and implementation capabilities, can maintain and service the ERP software system, can solve the problems encountered by the enterprise application ERP software system process, Guide the entire process of the implementation of enterprise software systems, and the specific business processes of different industry companies in the ERP software system to develop the appropriate business solutions. "Table I" will show the careeroriented positions of business management specialty (management informationization direction).

TABLE I. THE CAREER-ORIENTED POSITIONS OF BUSINESS MANAGEMENT SPECIALTY (MANAGEMENT INFORMATIONIZATION DIRECTION)

\begin{tabular}{|c|c|}
\hline Manufactures Company & ERP Software Supplier \\
\hline ERP Application Specialist & ERP Service Consultant \\
\hline ERP system administrator & ERP Sales Consultant \\
\hline $\begin{array}{c}\text { Corporate Information } \\
\text { Officer }\end{array}$ & ERP Implementation \\
Consultant \\
\hline \multicolumn{2}{|c|}{ Management Consultant } \\
\hline \multicolumn{2}{|c|}{ ERP Supervision Engineer }
\end{tabular}

In order to achieve the goal of talents training in this specialty, the differences in the training specifications of information management specialty and other professional talents are reflected, reflecting the characteristics of talents management of business management specialty (Management informationization direction). Higher vocational colleges need to combine the different job positions of the company and their skill requirements, and formulate professional talents training programs based on the growth process of students' professional positions. Based on the investigation of corporate and social needs, the curriculum structure and content of the practice curriculum need to be innovated, and practical teaching methods and teaching models need to be innovated to cultivate more specialized talents that meet the actual skill needs of the company.

\section{Professional Practice Course Teaching Content DESIGN}

\section{A. The Pertinence and Applicability of Practical Course Teaching Content}

In response to the requirements for talents training specifications for the business management specialty (management informationization direction), when designing the contents of the professional practice curriculum system, it is necessary to closely focus on the two goals of management technology and ERP application skills, takes the enterprise's ERP system project as the carrier and the "Changzhou Information Co., Ltd. ERP software system application and implementation" as the main line, the whole process of business processing is divided into three major modules: supply chain management, manufacturing management, and financial management. In each module, task-driven training for practical skills integrates the entire process of implementing ERP projects into different courses in the practice system. In the "ERP Principles and Applications" course, we focus on the basic data preparation for enterprises, functional training of ERP systems, business process reengineering, system implementation and project acceptance delivery. In the "ERP Project Management" course, we focus on training students' ERP system planning, enterprise business model blueprint design, cost and schedule control, and risk control. In the course of "Financial Informationization", the emphasis is placed on the practice of students' financial business processing capabilities and financial informationization capabilities. In the "ERP Secondary Development" course, we focus on the personalization needs of the company, and carry out secondary development in the ERP software system. Through the division of labor and collaboration of practical teaching tasks among different courses, the scope of practice courses will include all the business departments of the enterprise, and it also covers all the business types of the enterprise.

Through the study of professional practice curriculum system, students can systematically grasp modern enterprise management methods, management concepts, ERP theory, and systematically understand the role, scope, and main technologies of enterprise informationization, understand the content and methods of internal functional affairs management, ERP system development process, technology development, and module structure, and at the same time use the management concepts and methods learned for the enterprise to build and apply information systems (mainly ERP software systems), such as: supply chain business management, storage inventory business management, enterprise information project needs analysis and research, project feasibility analysis and overall information system planning. According to the requirements of the enterprise information system construction, students trained in higher vocational colleges will not only operate the ERP software system, but also analyze and optimize the existing business processes of the enterprise, analyze the business solution of ERP system according to the business function of the functional department, train ERP software for the enterprise staff, help the enterprise to choose the appropriate information system construction plan and implementation method, organize, collect and input the information data, students will carry out system initialization and specific ERP customization work, manage and control ERP project implementation time, schedule, cost and risk, and also perform simple performance evaluation on ERP projects. Therefore, in terms of applicability, the practical teaching content of the business management specialty (management informationization direction) includes both the management technology and the operational application technology of ERP, which is in line with the skill requirements of the students' professional growth process.

\section{B. Selection of Practical Course Teaching Content}

The selection of teaching content in the professional practice curriculum system is mainly accomplished through two phases of work. In the first stage, through the investigation of the requirements for ERP management talents of 
manufacturing enterprises in the region (ERP system users), the specific responsibilities and required job skills of information management jobs were obtained. At the same time, it communicated and researched with ERP software suppliers and implementation service providers to understand the job responsibilities and skill requirements of ERP implementation consultants. In the second stage, the members of the course group discussed together and determined the teaching content and teaching sequence of the specific practical courses according to the requirements of the enterprise for informationized talents, especially the requirements for the application and implementation of ERP software. The practical teaching sequence complies with the principle which is from easy to difficult and from single to integrated, and gradually formed through the course to complete the accumulation of job skills.

The aim of professional training in business management specialty (management informationization direction) is that a highly skilled composite talent who understands both management technology and information technology. The contents of the professional practice curriculum system mainly include three aspects: First, special management skills training. It mainly trains students' special management skills so that students can understand and master the business process of each sub-module within the company. Such as corporate cognitive training, basic accounting training, business operation training, business management and actual combat training, production planning management training, financial information training; The second is special information technology application training, mainly training students' information technology applications, such as computer application training, network operating system training, database application training, program design and development training; The third is the project's comprehensive application and implementation of training, mainly training students to apply various management skills and management methods in the ERP system platform, such as ERP principles and application training, ERP project management and implementation of training, mainstream ERP software System operation training, graduation design and internship. The selection of teaching content includes both management technology and information technology, which deepens the comprehensive skills of ERP application and implementation.

\section{Arrangement of Practical Course Teaching Content}

According to the different training objectives of the knowledge and skills in the teaching process, the arrangement of the teaching sequence of the practical course has also been emphasized. In the special management skills training, students will have a certain degree of professional orientation and career development through the "professional cognitive training". Through "business management and actual combat training", students will understand the business process of the company and the coordinated operation of various departments. Through the "basic accounting training", students will understand the process of corporate financial work. In information technology special training, through special training in databases, operating systems, OFFICE application and programming, students will understand the relevant information technology support of ERP software system, master the company's daily office document production and management, the mainstream database management system, the method of program development and design, the establishment of enterprise networks and system management technology.

In the project comprehensive application and practical training, Through the "ERP Principles and Application Training" ,students will understand what is ERP, what problems is the ERP can help companies to solve, how the company's internal business will be dealt with by ERP. Through "ERP project management and implementation training", students will grasp the implementation process of ERP projects and methods of project management and control. By graduating the design and internship, students will go deep into the company's work site and have a more intuitive understanding of the company's information projects, solving practical problems for the company. By using of a practical teaching base outside the school, students will combined with the company's real information construction projects; it will cultivate and reinforce students' project implementation and management capabilities, and enhances their practical experience.

\section{InNOVATION OF PRACTICAl COURSE TEACHING MOdEL}

The teaching model of practical courses adopts projectoriented and task-driven teaching methods. The implementation of enterprise ERP projects is the main line, and the learning process of students' practical courses is the implementation process of participating in specific projects of enterprises. At the beginning of the implementation of ERP project, students first had a perceptual understanding of ERP, through the guidance of teachers to generate interest in the ERP system, and stimulate students to further explore and learn the subjective initiative of the ERP software system. Through teacher's teaching of ERP principles, development stages and other contents, students have a rational understanding of ERP, and brought rational knowledge into all stages of project implementation, achieving the unity of knowledge and practice, and also realizing the combination of theory and practice. Through the integration of perceptual knowledge, rational knowledge, Integration of knowledge and skills, students will acquire deep theoretical knowledge and strong ERP application and implementation capabilities. The innovation of the professional course teaching model for business management (management informationization direction) mainly includes the following points.

\section{A. Design Teaching Projects According to Work Process}

The courses' content and their teaching sequence are completely designed according to the process of the enterprise application and implementation of the ERP system. For example, in the "ERP Application Training" course, according to the enterprise's ERP system implementation process, enterprise ERP project preparation, blueprint design, system training, on-line operation and system acceptance, enterprise ERP implementation process as shown in Figure 2 below. The specific implementation work includes the enterprise's understanding of ERP, needs analysis, business process reorganization, ERP training, data collation, input of original 
data, prototype testing, software on-line and operation, project acceptance and other specific issues. When setting the content and modules of these courses, and also identifies the corresponding ability training projects and tasks. Combining the practice teaching project with the work process of the enterprise ERP software system application and implementation, the process of embodying professional learning is the implementation process of the enterprise ERP project, thereby cultivating students' professional job skills and qualities.

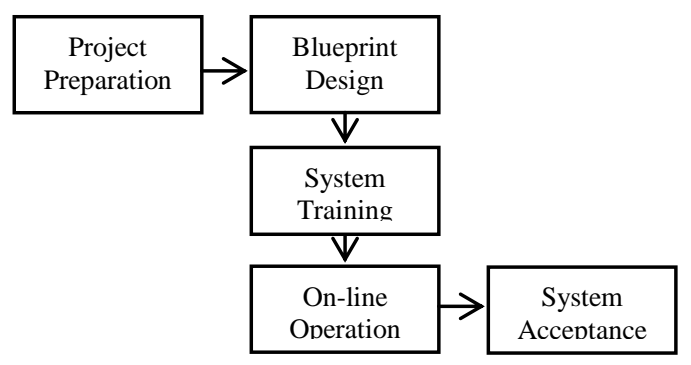

Fig. 1. Enterprise ERP system implementation process.

\section{B. Work-study Interchange Training Is Used During the Course of Teaching, Examining Students' Professional Skills through Corporate Projects}

In the course of practical course teaching, teachers of the course group use the work-study combination training base established with the manufacturing enterprise in the college information industry park, and arranges the students for a onemonth work-study interchange. In the work-study interchange, students apply the theoretical knowledge learned in the school to the practical work of the company, in the company's specific jobs, according to different business processes using ERP software for business processing, so that learning while doing, learning and practicing, For example, Enter purchase orders, fill arrival notices, issue sales invoices, fill warehouse receipts and other documents. Through the work-study interchange, students truly understand the specific scenarios of enterprise application of ERP, understand the process flow of enterprise business and the value that ERP brings to enterprises, and how companies apply and maintain ERP systems. In practice teaching activities of work-study interchange, students' ERP application and implementation skills have been effectively tested, and theoretical knowledge has also been verified by the company's actual work.

\section{Practice Training Program Is Enterprise-oriented, Modern Apprenticeship Is Used in Enterprise Practice Process}

In the school's manufacturing informatization talent training base, the main line of teaching of practical courses is the business process flow of each department of company, According to the company's actual business data and production and operation process, using ERP software system to truly reproduce the enterprise ERP system application and implementation of the scene. The teaching cases of all practical courses in business management (management informatization direction) are from the data of school-enterprise cooperation enterprises. The actual work data of 35 enterprises are used as the carrier to implement the comprehensive management skills, special information skills and project implementation skills. For example, according to the company's business process in the ERP system, the entire process of the company's production and operation will be incorporated into the teaching process of the practical course, from the customer sales order receipt, product $\mathrm{BOM}$ design, process route setting, preparation of production team and factory calendar, arrangement of main production schedule, material requirement planning, purchase plan, inventory management, release of production tasks and report of workshop process assignment. Finally, the entire process of enterprise business processes, data, and reports is simulated and emulated to form the integration of internal business data and business integration between upstream and downstream companies. Students are allowed to simulate the work content of different positions in the company and experience the application and business process flow of the enterprise information system in different positions. In the practice teaching outside the school, implements corporate mentors. Special tutors, corporate department directors, and senior consultants provide specific business guidance to students. Each student has two tutors, at the end of the practice, the company's mentor and school tutors will jointly evaluate the results, and realize the diversified evaluation of theoretical knowledge, job skills, and actual work effectiveness.

\section{Implement the Integrated Teaching Method of Theory and Practice and Build a Skill Training System Based on the Work Process of ERP Engineer}

Skills' training in practical courses adopts project-oriented, task-driven, and scenario-based integrated skills-training teaching, In the course of course teaching, the main line is the business process flow of the internal functional departments of company, mainly based on training operations, and the theoretical knowledge and practical ability are unified.

First, scenario simulation and task-driven is used for enterprise projects. According to the actual work content of each department, the project task is decomposed to form a student work group and a task task group. Each group completes the task group of the corresponding sub-module. In this way, all teams work together to complete large modules of work tasks and train students' communication and collaboration skills and teamwork. Second, the transformation of professional roles is achieved in the teaching process. In the practical environment of simulation, the professional teacher is transformed into an ERP implementation consultant for the enterprise. The student's identity is converted into the company's staff and the implementation of consultant-style onsite teaching is implemented. The whole process of implementing enterprise ERP projects was moved into practical classrooms. The relationship between teachers and students in teaching and learning was transformed into the cooperative relationship between ERP implementing staff and enterprise staff according to the job content of different positions, and also converted to ERP engineers training and mentoring ERP systems for employees, so that both teachers and students can complete the project implementation process together. Thirdly, the task is modularized, and the training of 
special management skills and information skills is integrated into vocational training. The programs of practical courses are divided into three major functional modules: ERP software system in finance, supply chain and manufacturing. The three functional modules together constitute a curriculum training content system that focuses on "professional mission orientation, practice project main lines, and business processes as carriers".

\section{CONCLUSION}

Higher vocational colleges should closely follow the skills requirements of professional talents of enterprise information management. In the selection of professional practice teaching content, it is necessary to analyze the work content and skill requirements of different jobs in different-type companies, and to cultivate information management talents who are both knowing management skills and understanding Information technology. In the pertinence and applicability of professional practice teaching content, combined with the content of enterprise informationization work, the implementation of information projects is used as a carrier, and the teaching of practical courses is integrated into the whole process of project implementation. At the same time, in the teaching sequence of the professional practice courses, we follow the principles of easy-to-preceding, simple-to-synthesize, and gradually increase the students' level of information application and ability.

In the practical course teaching model of information management specialty in higher vocational colleges, a new type of teaching model is used to integrate the skills learning and exercise process into the implementation process of the enterprise informationization project, corresponds with the professional skills required for the job and the tasks in the work process, and the process of student's curriculum learning and the solving work tasks is also the accumulation of professional competence. At the same time, in the teaching form of professional practice courses, the talents training model of the work-study interchange is implemented, and the theoretical knowledge and the enterprise practice are unified, so as to learn and practice while learning. In the practical teaching in the school, the actual situation of the enterprise is used to simulate for school practical environment. In the teaching, the transition from the teacher-student relationship to the ERP implementation consultant and the employee's relationship is realized. In addition, in the teaching evaluation of practical courses, each student implements a "double-tutoring system" that combines a campus tutor and a corporate tutor, and implements multi-faceted practical curriculum teaching evaluations such as school tutors, corporate tutors, and department heads. Higher vocational colleges have explored a talent training model that meets the professional growth of students through the continuous innovation and practice of the practical teaching model of information management specialty, so as to better serve the information management talents required by enterprises and society.

\section{ACKNOWLEDGMENT}

The author acknowledges the valuable comments and suggestions of Editors, conference participants at the 4th
International Conference on Arts, Design and Contemporary Education (ICADCE 2018).

\section{REFERENCES}

[1] Yang Zongkai, Yang Hao, Wu Yi. On the Deep Integration of Information Technology and Contemporary Education[J]. Education Research, 2014(3): 93-94.

[2] Chen Bi-qun. Construction of Practical Curriculum System for Electronic Information Specialty in Higher Vocational Colleges[J]. China Vocational and Technical Education, 2012(11): 6-7.

[3] Fan Bianfu. Thinking on the Construction of Practice Curriculum System in Higher Vocational Education [J]. Vocational Education Forum, 2015(12): 44.

[4] Jin Jingmei. Research on the Practical Course System Construction of "Subject to Dock, Stages, and Helical Progressive" in E-commerce Specialty in Higher Vocational Education [J]. Vocational Education News, 2016(8): 2-3.

[5] Daryl Powell, "ERP systems in lean production: new insights from a review of lean and ERP literature," International Journal of Operations \& Production Management, vol. 33, pp. 1490 - 1510, 2013.

[6] Nabeel M. Albashiry, Joke M. Voogt, Jules M. Pieters. Improving curriculum development practices in a technical vocational community college[J], The Curriculum Journal, 2015, Vol.26 (3), pp.425-451

[7] Adnan Ahmad,Nadia Ab Latib. Teaching in Automotive Practical Task: Practices in Vocational Colleges[J]. Procedia - Social and Behavioral Sciences, 2015,204.

[8] Rizwan Muhammad, Nisa Fakharun,Adeel Muhammad, Ramzan Muhammad, Lal Mohan Baral. Impact Of Instructional Technology Inclusions In Course Delivery For Engineering And Business Education[J]. Balkan Region Conference on Engineering and Business Education,2014,1(1). 